\title{
KRITIK HADIS ZIKIR BERJAMA'AH
}

\author{
Febriyeni \\ LAIN Bukittinggi,febriyeni703@gmail.com
}

\author{
Diterima: 12 Januari 2018
}

Direvisi : 23 Maret 2018

Diterbitkan: 30 Juni 2018

\begin{abstract}
It is still a conversation by Muslims about how to implement true remembrance, because the Qur'anic explanation of the problem of remembrance is very common. Whereas the Prophet's hadith also provides various information on this matter. The guidance of the hadith about the implementation of remembrance rests on the deeds done by the Prophet, then imitated and imitated by his friends and became the practice of the Sunnah for Muslims to date. One of the issues discussed is the implementation of zikir in congregation (zikir jama'i). Remembrance in congregation is a gathering of several people with one voice chanting dhikr. There are pros and cons regarding the implementation of remembrance in this congregation. There are groups who think. that remembrance in congregation is an act of bid'ah and vice versa there are those who consider that the act is sunnah. This paper will discuss the issue, seen from the perspective of hadith. This study uses the library research method by tracing the traditions related to remembrance in congregation followed by criticism of the sanad and the matan hadith, as well as an understanding of these traditions.
\end{abstract}

Keywords: Critics, Hadis, Zikir Berjamaah

\begin{abstract}
Abstrak
Masih menjadi perbincangan oleh umat Islam tentang bagaimana pelaksanaan zikir yang benar, karena penjelasan al-Qur'an tentang persoalan zikir ini sangat umum. Sedangkan hadis Nabi memberikan informasi yang beragam pula mengenai hal ini. Tuntunan hadis tentang pelaksanaan zikir bersandarkan kepada amalan yang diperbuat oleh Rasulullah Saw, kemudian dicontoh dan ditiru oleh sahabat-sahabatnya dan menjadi amalan sunnah bagi umat Islam sampai saat ini. Salah satu persoalan yang diperbincangkan adalah pelaksanaan zikir secara berjama'ah (zikir jama'i). Zikir berjamaah adalah berkumpulnya beberapa orang dengan satu suara melantunkan zikir. Terdapat pro-kontra mengenai pelaksanaan zikir berjama'ah ini. Ada kelompok yang menganggap bahwa zikir berjama'ah adalah suatu perbuatan bid'ah dan sebaliknya ada yang menganggap bahwa perbuatan tersebut adalah sunnab. Tulisan ini akan membahas persolan tersebut, dilihat dari perspektif hadis. Penelitian ini menggunakan metode library research dengan melakukan penelusuran terhadap hadis-hadis yang terkait dengan zikir berjamaah dilanjutkan dengan kritik sanad dan matan hadis, serta pemahaman terhadap hadis - hadis tersebut.
\end{abstract}

Kata Kunci: Kritik, Hadis, Zikir Berjamaah

\section{PENDAHULUAN}

Secara etimologi, perkataan zikir berakar pada kata ذَكَرَ، يَذْكُرُ، ذِكْرًا mengingat, memperhatikan, mengenang, mengambil pelajaran, mengenal atau mengerti dan ingatan. Di dalam Ensiklopedi Islam menjelaskan bahwa istilah zikir memiliki multi interpretasi, di antara pengertian zikir adalah menyebut, menuturkan, mengingat, menjaga, atau mengerti perbuatan baik. ${ }^{1}$ Sedangkan menurut terminologi adalah membasahi lidah dengan ucapan-ucapan pujian dan pengagungan kepada Allah Swt. ${ }^{2}$ Menurut Aboe Bakar Atjeh, dalam bukunya Pengantar Ilmu Tarekat Uraian Tentang Mistik. Zikir adalah ucapan yang dilakukan dengan lidah, atau

1 In'ammuzahiddin Masyhudi, Nurul Wahyu A, Berzikir dan Sehat ala Ustad Haryono, ( Semarang: Syifa Press, 2006) h. 7

Masyharuddin, $\quad$ Pemberontakan
Tasawnf,(Surabaya :Stain Press Kudus, 2007),
cet 1, h. 245 
mengingat Allah dengan hati, dengan ucapan atau ingatan yang mensucikan Allah dengan memuji dengan puji-pujian dan sanjungansanjungan dengan sifat yang sempurna, sifat yang menunjukkan kebesaran dan kemurnian. ${ }^{3}$ Dalam pelaksanaan zikir tersebut terdapat ikhtilaf/ perbedaan. Ada yang menyerukan agak zikir itu dilaksanakan sendiri sendiri dan ada pula yang menyerukan untuk melaksanakan zikir secara berjamaah atau ekrap dikenal dengan istilah zikir jama’i.

Syekh Dr, Muhammad bin Abdurrahman al Khomis mengatakan Zikir Jama’i adalah kegiatan yang dilakukan sebagian orang, (seperti berkumpul setelah sholat lima waktu atau di waktu dan keadaan lainnya), untuk mengulang-ulang zikir, doa atau wirid dengan suara bersama, dan dipimpin oleh satu orang atau tanpa ada yang memimpin, tapi mereka membaca zikir-zikir dengan cara bersama-sama dengan satu suara. ${ }^{4}$

Terdapat iktilaf ulama mengenai pelaksanaan zikir berjama'ah ini. Ada ulama yang menganggap bahwa zikir berjama'ah adalah suatu perbuatan bid'ah dan sebaliknya ada yang menganggap bahwa perbuatan tersebut adalah sunnah. Setiap pendapat memiliki dalilnya masing-masing. Dalam tulisan ini penulis akan melakukan kritik hadishadis zikir jama'i.

\section{METODE PENELITIAN}

Metode penelitian adalah strategi umum yang digunakan dalam pengumpulan data dan analisis data yang diperlukan untuk menjawab persoalan yang diajukan. Maka secara metodis, peneliti akan menyajikan perihal jenis penelitian, pendekatan penelitian, teknik penggalian dan analisis data yang

\footnotetext{
3 Aboe Bakar Atjeh, Pengantar Ilmu Tarekat Uraian tentang Mistik, (Solo: Ramadhani, 1996), h. 276

4 Muhammad bin Abdurrahman al Khomis, Zikir Jama'I bainal ittiba wa ibtida', ( Al Manshurah, Dar Al Huda An Nabawi, 2004 ), h. 11
}

digunakan dalam penelitian ini. Jenis penelitian ini adalah penelitian kepustakaan (library research), yaitu penelitian yang berusaha mendapatkan dan mengolah data berdasarkan sumber kepustakaan seperti buku, artikel, jurnal, majalah, ensiklopedi dan sumber dokumentasi lainnya. Dalam penelitian kepustakaan ini penulis menelusuri datadideskripsikan secara kritis dalam laporan penelitian. Pendekatan yang dipakai adalah pendekatan kualitatif, artinya prosedur penelitian yang menghasilkan data deskriptif berupa kata tertulis atau lisan dari orang-orang dan perilaku yang diamati. ${ }^{5} \mathrm{Di}$ antara signifikansi penelitian kualitatif adalah untuk menghasilkan pengkajian mendalam dalam upaya menemukan perspektif baru tentang halhal yang sudah diketahui.

Teknik penggalian data sesuai dengan jenis pendekatan penelitiannya, yaitu pendekatan kualitatif, maka teknik penggalian datanya dilakukan dengan cara menelaah dan menganalisis sumber-sumber data yang ada, kemudian dari telaah dan analisis tersebut hasilnya dicatat dan diklasifikasikan sesuai dengan kerangka yang sudah direncanakan. Data-data yang diperoleh dari kepustakaan akan dianalisis secara kualitatif dengan beberapa tahap. Pertama, editing yaitu memeriksa kembali semua data yang diperoleh terutama dari segi kelengkapan, keterbacaan, kejelasan makna, kesesuaian dan keselaras satu dengan lainnya relevansi dan keseragaman satuan kelompok data. Kedua pengorganisasian data yaitu menyusun dan mensistematiskan data-data yang diperoleh ke dalam kerangka paparan yang direncanakan. Ketiga melakukan analisis lanjutan terhadap hasil pengorganisasian data, dengan menggunakan kaidah, teori, dalil dan sebagainya yang berkenaan dengan pembahasan, sehingga memperoleh

5 Lexy J. Moleong,, Metodologi Penelitian Kualitatif, (Bandung: Remaja Rosdakarya, 2008), h. 131 
kesimpulan, dengan menggunakan metode analisis deskriptif, yaitu data yang dikumpulkan berupa kata-kata dan bukan angka-angka. ${ }^{6}$ Sedangkan penyimpulannya digunakan jalan berfikir berikut: a) Induktif yaitu suatu cara dalam menerangkan suatu masalah dimulai dari permasalahan yang bersifat khusus untuk ditarik pada kesimpulan secara umum. b) deduktif : yaitu suatu cara menerangkan masalah dimulai dari yang umum (hasil riset) kemudian diterangkan secara bertahap menuju kesimpulan yang bersifat khusus. ${ }^{7}$

\section{PENELUSURAN HADIS-HADIS TENTANG ZIKIR BERJAMA'AH}

Penelusuran hadis-hadis tentang zikir berjama'ah atau hadis yang dianggap memiliki isyarat akan adanya zikir berjama'ah dapat dilakukan melalui beberapa referensi buku atau hasil penelitian yang terkait dengan hadis tersebut. Beberapa refensi tersebut menjadi rujukan untuk penelusuran terhadap hadishadis zikir berjama'ah, sehingga diperoleh informasi sebagai berikut: ${ }^{8}$

\begin{tabular}{|c|c|c|}
\hline No & $\begin{array}{l}\text { Kata } \\
\text { Kunci }\end{array}$ & Ditemukan informasi \\
\hline 1 & ونحلسنا نذكر الله & $\begin{array}{l}\text { Shahih Muslim, kitab zikir } \\
\text { nomor } 40\end{array}$ \\
\hline$r$ & ذكر في ملاء & $\begin{array}{l}\text { Shahih Muslim kitab zikir } \\
\text { nomor 2, 18, 19, 21, } \\
\text { Shahih Bukhari kitab } \\
\text { tauhid nomor 15, 43, } \\
\text { sunan al-Tirmidzi kitab } \\
\text { da'wat nomor 131, sunan } \\
\text { Ibn Majah kitab Adab } \\
\text { nomor } 53 \text { dan 58, Ahmad } \\
\text { bin Hambal jilid } 2 \\
\text { halaman 251, 405, 413, }\end{array}$ \\
\hline
\end{tabular}

${ }^{6}$ Ibid. h. 131

${ }^{7}$ Ibid. h. 131

8 Doni Rahmat, Tesis: Zikir Berjama'ah dalam Perspektif Hadis, ( Program Pasca Sarjana IAIN Padang, 2013), h.76

\begin{tabular}{|c|c|c|}
\hline & & $\begin{array}{l}454,480,482,516,517, \\
524,534,540\end{array}$ \\
\hline$r$ & يذكرون الله & $\begin{array}{l}\text { sunan al-Tirmidzi kitab } \\
\text { da'wat nomor 108, } \\
\text { 14,129, bab Haji nomor } \\
\text { 98, Sunan Abi Daud kitab } \\
\text { 'Ilmu nomor 13, Shahih } \\
\text { Muslim kitab Zikir nomor } \\
\text { 39, Sunan an-Nasa'I kitab } \\
\text { Mawaqit nomor 55, kitab } \\
\text { Azan nomor 23, sunan } \\
\text { Ibn Majah kitab Adab } \\
\text { nomor 53, 54, dan } \\
\text { Musnad Ahmad bin } \\
\text { Hambal jilid 3, halaman } \\
\text { 22. }\end{array}$ \\
\hline$\varepsilon$ & مجلسا فيه ذكر & $\begin{array}{l}\text { Shahih Muslim kitab zikir } \\
\text { nomor } 25\end{array}$ \\
\hline 0 & مجلس ذكر & $\begin{array}{l}\text { Sunan Abi Daud kitab } \\
\text { Adab nomor } 27\end{array}$ \\
\hline 7 & ما جلس قوم الله فيه & $\begin{array}{l}\text { sunan Ibn Majah kitab } \\
\text { Adab nomor } 53\end{array}$ \\
\hline V & مجلس جلس فلم & $\begin{array}{l}\text { Ahmad bin Hambal jilid } 2 \\
\text { halaman } 432,446, \\
453,481,484,490,527\end{array}$ \\
\hline$\Lambda$ & ملائكة يبتغون & $\begin{array}{l}\text { Shahih Muslim kitab zikir } \\
\text { nomor } 25\end{array}$ \\
\hline 9 & الذيمة بجالس & $\begin{array}{l}\text { Ahmad bin Hambal jilid } 2 \\
\text { halaman } 177,190\end{array}$ \\
\hline 1. & اهل الذكر & $\begin{array}{l}\text { Shahih Bukhari kitab } \\
\text { Da'wat nomor } 67 \text {, Shahih } \\
\text { Muslim kitab zikir nomor } \\
25\end{array}$ \\
\hline 11 & حلق الذكر & $\begin{array}{l}\text { Ahmad bin Hambal jilid } 3 \\
\text { halaman } 150\end{array}$ \\
\hline IT & بن بالذكر حين & $\begin{array}{l}\text { Shahih Bukhari kitab } \\
\text { Azan nomor 155, Abi } \\
\text { Daud kitab Shalat nomor } \\
\text { 185, dan Ahmad bin }\end{array}$ \\
\hline
\end{tabular}




\begin{tabular}{|l|l|l|}
\hline من المكتوبة & $\begin{array}{l}\text { Hambal jilid 1, halaman } \\
367\end{array}$ \\
\hline
\end{tabular}

\section{KRITIK SANAD DAN MATAN HADIS -HADIS ZIKIR BERJAMA'AH}

Hadis yang menerangkan tentang indikasi adanya zikir berjama'ah cukup banyak. Untuk itu penulis mengklasifikasikan hadishadis tersebut berdasarkan penggunaan istilah yang identik dengan kata jama'ah.

\section{Memakai Istilah Kaum}

Untuk hadis-hadis yang menggunakan istilah kaum terdapat tiga versi hadis, yaitu:

Hadis Pertama, Kaum yang berzikir dikerumuni malaikat, mendapat rahmat, sakinah dan sanjungan Allah. Hadis Riwayat Muslim dan Tirmidzi.

حدثنا محمد بن المثني وبن بشار قالا حدثنا محمد بن

جعفر حدثنا شعبة سمعت أبا إسحاق يحدث عن

الأغر أبي مسلم أنه قال أشهد على أبي هريرة وأبي

سعيد الخدري أفما شهدا على النبي صلى الله عليه

وسلم أنه قال * لا يقعد قوم يذكرون الله عز وجل إلا

حفتهم الملائكة وغشيتهم الرحمة ونزلت عليهم السكينة

وذكرهم الله فيمن عنده

Tidaklah duduk-duduk suatu kaum sambil berzikir kepada Allah Azza wajalla melainkan mereka dikerumuni malaikat dan dilingkupi rahmat, diberi sakinah, dan Allah menyebut mereka dihadapan malaikat yang ada di sisi-Nya.

Selain diriwayatkan oleh Muslim, hadis ini juga diriwayatkan oleh at-Tirmidzi, Ibn Majah, Ahmad dan Abu Ya'la. Hadis ini berkualitas shahih, karena termasuk riwayat dari imam Muslim. Setelah mengamati susunan lafal matan hadis ini dari sekian banyak jalur periwayatan, ternyata terdapat perbedaan lafal,

${ }^{9}$ Imam Muslim, Shabih Muslim, Kitab adz-dzir wa ad-du'a wa at-taubah wa istighfar, bab fadbl al-ijtima' ala tilawat al-qur'an wa ala adz-dziker, juz 4, h. 2074, dalam CD Maktabah Syamilah berikut ini redaksi lafal hadis yang berbeda namun maknanya sama dengan hadis di atas dari riwayat Tirmidzi:

حدثنا محمد بن بشار حدثنا عبد الرحمن بن مهدي حدثنا سفيان عن أبي إسحق عن الأغر أبي مسلم : أنه شهد على أبي هريرة و أبي سعيد الخدري إهما شهدا على رسول الله صلى الله عليه و سلم أنه قال ما الرحمة ونزلت عليهم السكرون الله إلا حفت بهم الملائكة وغشيتهم

Perbedaan lafal hadis di atas tidak mempunyai pengaruh yang signifikan terhadap makna hadis, karena hadis ini berusaha mengungkapkan keutamaan bagi kaum (kelompok) yang berzikir. Salah satu jalur riwayat hadis-hadis di atas melalui periwayatan Imam Muslim dan berkualitas shahih, sehingga tidak perlu dilakukan lagi kajian sanad yang lebih lanjut.

Adapun dari segi matan dapat diketahui bahwa pelaksanaan zikir bersama tergambar pada kalimat يقعد قوم dan من قوم . Istillah kaum tentu digunakan untuk sekelompok orang. Ini menunjukkan bahwa keutamaan yang dapatkan oleh kaum yang berzikir antara lain mendapat naungan dari malaikat, mendapat rahmat yang berlimpah dari Allah, mendapat ketenangan jiwa, dan mereka akan disebut Allah di hadapan malaikat yang ada di sisi-Nya.

Hadis Kedua, Kaum yang berzikir mendapat ampunan dan diganti dosa-dosanya dengan kebaikan, Riwayat Ahmad dan Abu Ya'la

${ }^{10}$ Imam Tirmidzi, Sunan at-Tirmidzi, Maktabah Syamilah 


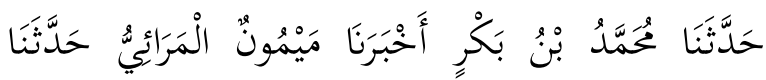

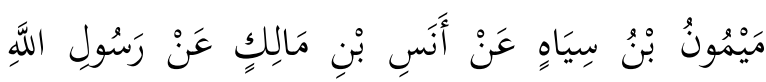

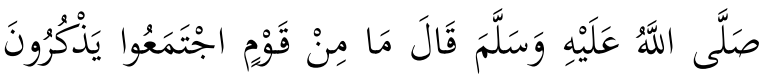

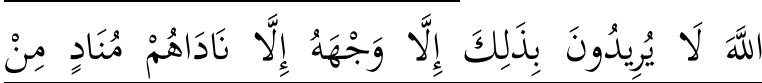

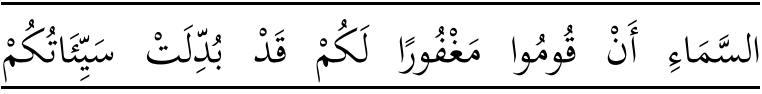

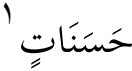

Tidaklah suatu kaum berkumpul sambil berzikir kepada Allah dan tidak ada maksud lain selain dariNya, maka mereka akan diseur dari langit untuk. berdiri dalam keadaan mendapatkan keampunan, dan segala dosa-dosa telab digantikan dengan kebaikan.

Selain diriwayatkan oleh Ahmad, hadis ini juga diriwayatkan oleh Abu Ya'la. Kedua Jalur Sanad bertemu pada Maimun bin marani dari Maimun bin Siyah dari Anas bin Malik. Kualitas sanad hadis ini dha'if karena ada perawinya yang dinilai dhaif yaitu Maimun bin Marani dan Maimun bin Siyah. ${ }^{12}$

Pelaksanaan zikir bersama terlihat dari

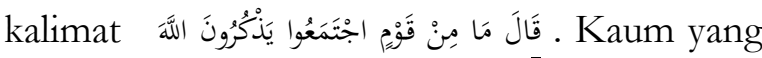
berkumpul mengindikasikan adanya kegiatan yang dilakukan bersama-sama. Dalam hadis dikatakan bahwa mereka berkumpul untuk melakukan zikir kepada Allah, sehingga mereka mendapatkan keutamaan di sisi Allah.

Hadis yang memiliki redaksi lafal yang berbeda namun makna yang dikandungnya hampir sama dengan hadis di atas, yaitu tentang ampunan bagi kaum yang berzikir, juga ditemukan dalam hadis riwayat Baihaqi sebagai berikut:

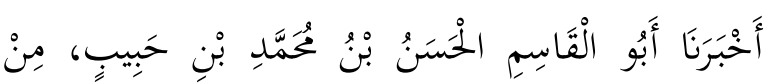

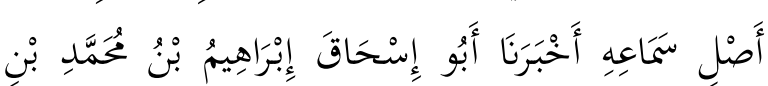

11 Ahmad bin Hambal, Musnad Ahmad, kitab Baqi Musnad al-Muktsirin, bab Musnad Anas bin Malik, no hadis 12476 Juz III, h. 142, Abu Ya'la, Musnad Abi Ya'la, no hadis 4141 Juz VII, h. 167

12 Lukmanul Hakim, Tuntunan Hadis Tentang Zikir, (Padang: Hayfa Press, 2013), h. 101

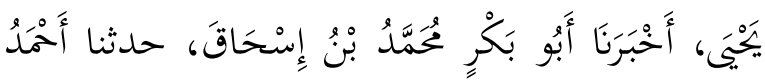

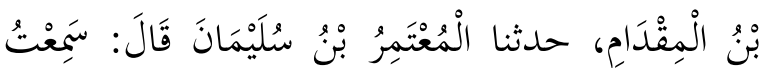

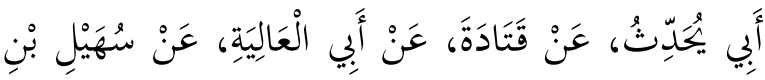

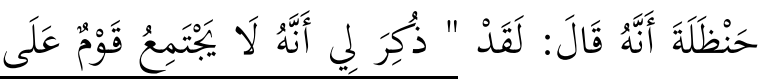

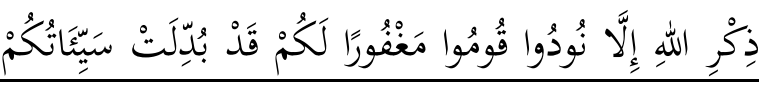

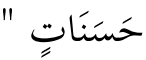

أخبرنا أبو عبد الله الحافظ ثنا أبو العباس الأصم ثنا

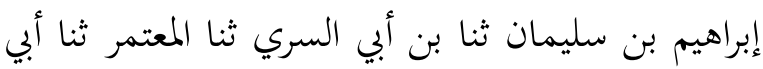
عن قتادة عن أبي العالية ثنا سهيل بن حنظلة قال قال

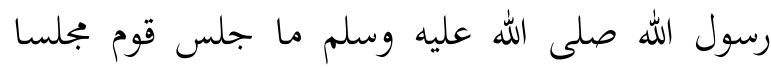

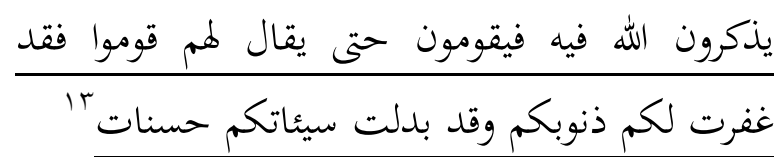

Dua hadis di atas sama-sama diriwayatkan dari Suhail bin Hanzhalah dari Abi Aliyah dari Qatadah, namun untuk jalur setelahnya terdapat perbedaan perawi.

Hal ini menunjukkan bahwa hadishadis tentang ampunan bagi kaum yang berzikir diriwayatkan dari 2 sahabat yaitu anas bin malik dan suhail bin hanzhalah. Meskipun riwayat ini lemah, karena ada perawinya yang lemah, namun hadis ini tidak bertentangan dengan riwayat lain.

Hadis Ketiga, Hadis tentang larangan bagi kaum dalam satu majelis yang tidak berzikir kepada Allah, Hadis Riwayat Tirmidzi حدثنا محمد بن بشار حدثنا عبد الرممن بن مهدي

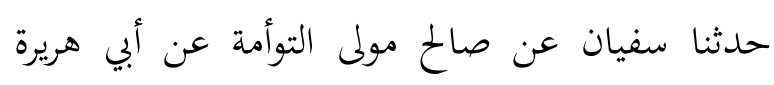

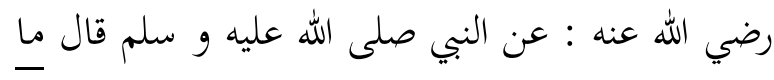

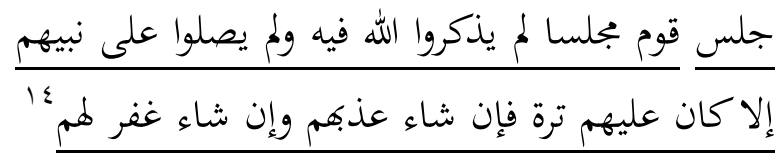

${ }^{13}$ Baihaqi, Maktabah syamilah

${ }^{14}$ Al-Tirmidzi, op.cit 
Tidaklah duduk-duduk suatu kaum dalam majlis yang tidak ada menyebut asma Allah dan tidak pula bersholawat kepada Nabi mereka melainkan bagi mereka tirah (kerugian), jika ingin, Allah akan mengazab mereka atau mengampuni mereka.

Hadis ini diriwayatkan dari Muhammad bin Basyar, dari Abdurrahman bin Mahdi, dari Sufyan dari Sholeh maula Thau'amah, dari Abu Hurairah. Doni Rahmat dalam tesisnya mengatakan bahwa hadis ini dinilai dhaif karena salah seorang rawinya yaitu Sholeh maula Thau'amah dinilai dha'if. Namun hal ini patut dikritisi karena Sholeh maula Thau'amah dinilai sebagai seorang tsiqah tsabat dan Thabiiyyun tsiqatun oleh Yahya bin Ma'in dan Jibilli. Di samping itu, hadis ini dikuatkan oleh banyak hadis lain yang semakna dengannya, ${ }^{15}$ Oleh karena itu, hadis ini dinilai oleh Tirmidzi sebagai hadis hasan shabih.

\section{Memaknai Istilah Halaqah}

Halaqab maksudnya adalah sekelompok orang yang duduk melingkar di mesjid untuk melakukan suatu kegiatan seperti diskusi atau berzikir. Berikut ini hadis yang menunjukkan zikir bersama dalam bentuk balaqah.

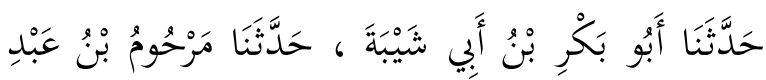

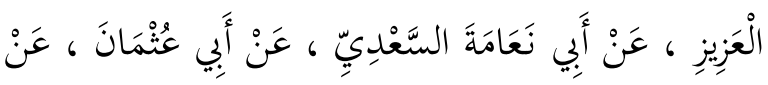

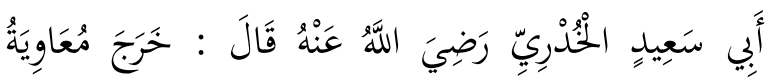

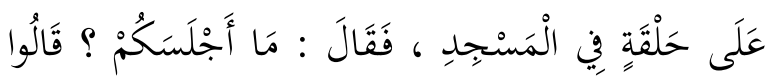

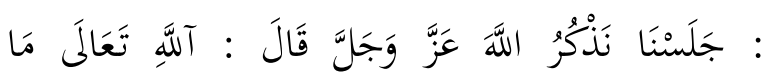

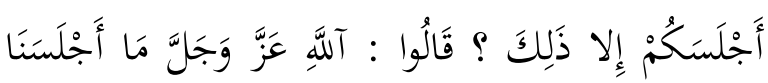

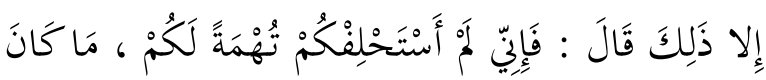

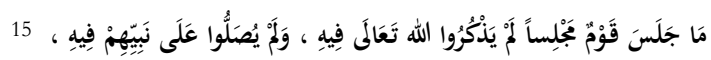

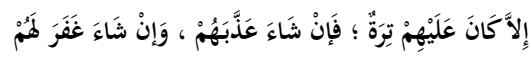

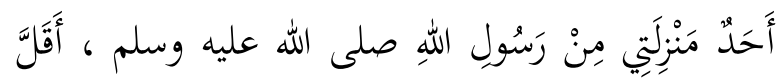

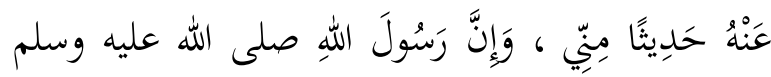

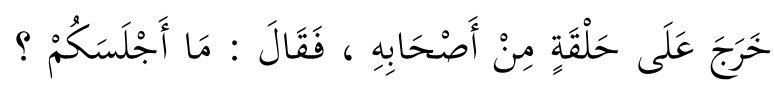

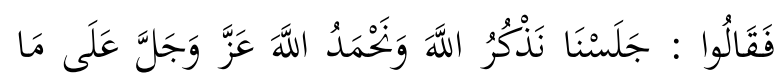

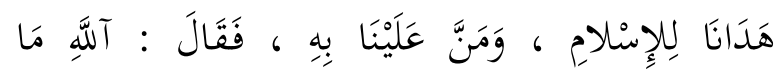

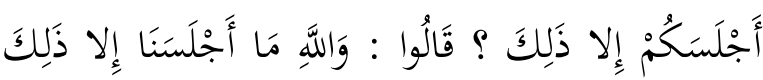

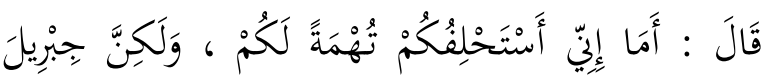

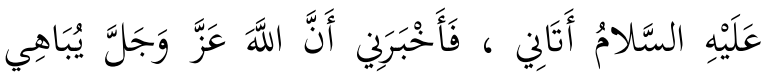

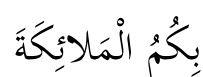

Muawiyah keluar menuju satu halaqah di mesjid. Lalu ia berkata apa yang membuat kalian dudukduduk? Mereka menjawab kami duduk-duduk mengingat Allah. Ia berkata demi Allah Kalian tidak duduk kecuali untuk itu? Mereka menjawab demi Allah kami tidak duduk kecuali untuk itu. Muawiyah berkata aku tidak meminta kalian bersumpah sebagai tuduhan kepada kalian. Tidak ada seorangpun yang berkedudukan sama denganku ini yang lebih sedikit meriwayatkan hadis dariku. Dan sesunggubnya Rasulullah saw keluar menuju satu halaqab dari para sababatnya. Lalu ia berkata, apa yang membuat kalian duduk-duduk? Mereka menjawab kami duduk-duduk mengingat Allah, ia berkata demi Allab kami tidak duduk-duduk kecuali untuk itu. Rasulullah berkata. Aku tidak meminta kalian bersumpah sebagai tuduban kepada kalian. Akan tetapi Jibril datang dan memberitabuku bahwa Allah azza wa jalla membanggakan kalian kepada malaikat.

Hadis ini diriwayatkan oleh Muslim dari Abu Bakar bin Abu Syaibah. Abu Bakar meriwayatkan dari Marhum ibn Abd Aziz dari Abu Na'amah al-Sa'di dari Abu Usman, dari Abu Sa'id al-Khudri. Dan Abu Sa'id menceritakan sekaligus meriwayatkan dari Muawiyah. Hadis yang senada juga diriwayatkan oleh Tirmidzi dan Ahmad, namun seluruhnya mengambil dari Marhum bin Abdul Aziz. Hadis ini memiliki 2 muttabi' dan karena diriwayatkan oleh Muslim, maka penelitian terhadap kualitas hadis adalah shabih. 
Hadis ini menjelaskan bahwa ada kelompok tabi'in yang membuat halaqah (duduk melingkar) dalam masjid, maka datanglah Muawiyah menanyakan apa yang mereka kerjakan, mereka menjawab bahwa mereka melakukan zikir kemudian Muawiyah menceritakan bahwa Rasulullah dulu pernah juga bertanya kepada sahabat yang melakukan hal yang serupa, lalu mereka menjawab bahwa mereka berzikir, pertanyaan ini diulanginya lagi seakan-akan beliau tidak percaya terhadap apa yang mereka lakukan, lalu Rasulullah menjelaskan bahwa Jibril mendatangi Rasulullah dan mengatakan bahwa Allah membangga-banggakan sahabat tadi kepada para malaikat.

Dari penjelasan hadis ini dapat dipahami bahwa zikir dalam sebuah halaqab sangat baik dan sangat disenagi oleh Allah, namun Lukmanul Hakim memahami bahwa pelaksanaan zikir dalam sebuah balaqah tersebut dilakukan dengan sirr, karena Rasulullah tidak mengetahui apa yang dilakukan sahabat dalam masjid. Jadi kebiasaan zikir bersama yang dilakukan oleh sahabat dan tabiin yang dijelaskan dalam hadis yaitu dengan sir.

\section{Memakai Istilah Mala' (ملاء)}

Maksud dari istilah ini adalah keramaian. Ini menunjukkan adanya orang banyak yang berzikir. Berikut hadis tentang zikir yang memakai istilah ini

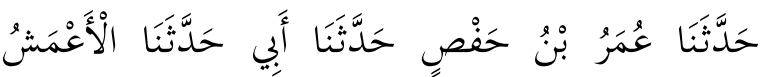

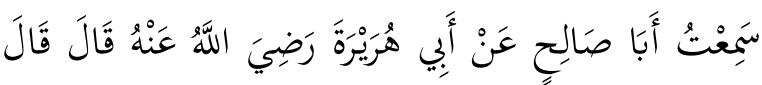

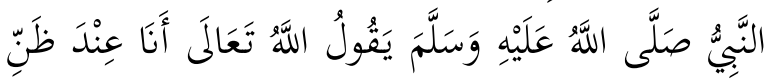

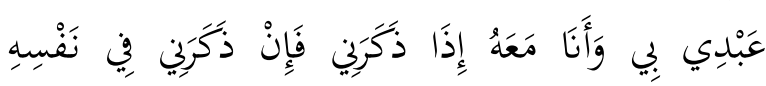

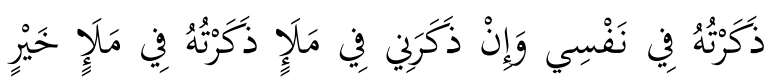

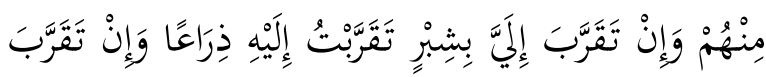

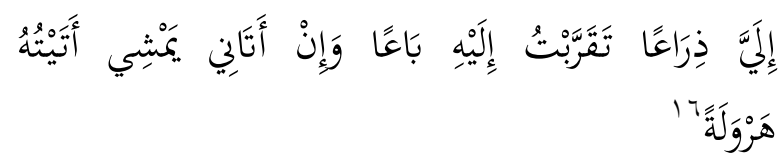

Aku sesuai dengan sangkaan hambaku terbadapku dan aku bersamanya apabila ia mengingatku. Jika ia mengingatku dalam keadaan kesendiriannya maka aku mengingatnya dalam kesendirianku. Jika ia mengingatku di keramaian maka aku akan mengingatnya di keramaian yang lebih baik lagi. Apabila ia mendekat kepadaku sejengkal maka aku akan mendekatinya sehasta, jika ia mendekatiku sehasta maka aku akan mendekatinya sedepa, jika ia mendatangiku sambil berjalan maka aku akan mendatanginya dengan berlari.

Hadis ini diriwayatkan oleh Bukhari dari Umar bin Hafs dari Hafs, dari al-A'masy dari Abu Sholeh dari Abu Hurairah. Hadis ini diriwayatkan melalui 9 jalur sanad. Di antaranya imam Bukhari, 2 jalur sanad oleh imam Muslim, al-Timidzi dan 5 jalur sanad oleh imam Ahmad. Hadis ini termasuk hadis yang Muttafaqun Alaib.

Ibn Hajar memahami dzakara fi malain dengan makna dzakarani jahran. Artinya adalah mengeraskna suara di saat ada banyak orang yang akan mendengarnya. Di dalam Tuhfatul Abwari kata ini ditafsirkan dengan ma'a jama'ah minal mukminin. Maksudnya adalah berzikir bersama sekelompok kaum mukmin. Kedua pemaknaan ini sangat dekat dengan tema zikir berjamaah.

Hadis ini menjelaskan tentang pelaksanaan zikir secara sendiri maupun dalam sebuah kelompok atau jamaah. Menurut hadis ini bahwa Allah sesuai dengan prasangka hambanya dan Allah akan selalu bersama hambanya selagi mereka berzikir. Menurut hadis ini zikir itu boleh ditempat yang sunyi dan dilakukan sendiri dan juga boleh dilakukan ditempat yang ramai dalam satu kelompok.

\section{Memaknai Kata Hilaqu adz-Dzikr}

16 Muhammad bin Ismail bin Ibrahim almughirah bin bardazbab albukhari, shabih bukhari, maktabah syamilah. 


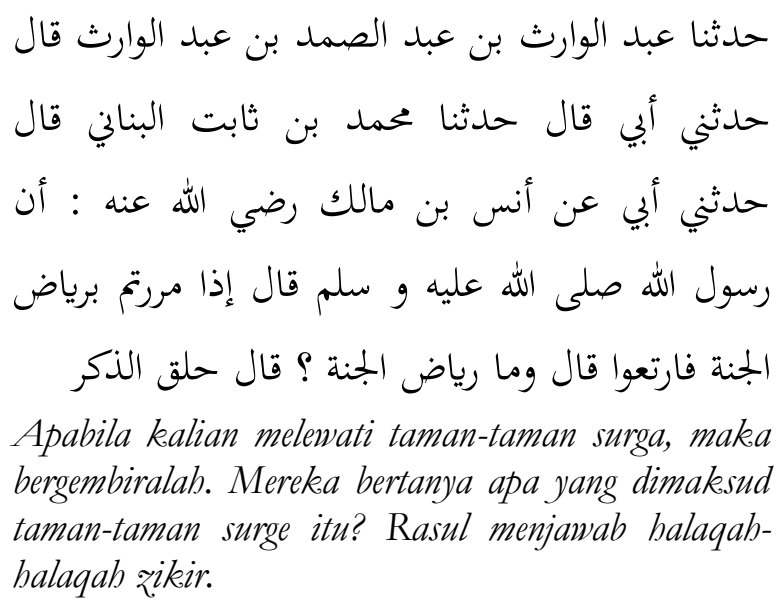
bergembiralah. Mereka bertanya apa yang dimaksud taman-taman surge itu? Rasul menjawab balaqabhalaqah rikir.

Selain diriwayatkan oleh at-Tirmidzi, hadis ini juga diriwayatkan oleh Ahmad dan Abu Ya'la. Sanad hadis ini berkualitas dhaif karena salah seorang perawi pada sanad hadis ini dinilai dhaif yaitu Muhammad bin Tsabit. Di antara penilaian terhadap Muhammad bin Tsabit adalah penilaian dari Abu Hatim yang menilainya munkar al-hadis, Yahya bin Ma'in menilai laisa bisyain, Abu Daud, An-Nasai dan Daruquthni menilainya dhaif.

Hadis ini memotivasi sahabat dan umat untuk tekun mengikuti halaqah zikir, karena pada hadis ini balaqah zikir diumpamakan sebagai taman-taman surga. Matan hadis ini tidak bertentangan dengan hadis yang lain.

\section{Memaknai Istilah Majalis adz-Dzikr}

Adapun hadis tentang majalis adz-zikir terdapat dua hadis sebagai berikut:

Hadis Pertama,

حدثنا محمد بن حاتم بن ميمون حدثنا بهز حدثنا وهيب حدثنا سهيل عن أبيه عن أبي هريرة عن النبي صلى الله عليه وسلم قال * إن لله تبارك وتعالى ملائكة سيارة فضلا يتبعون مجالس الذكر فإذا وجدوا بجلسا فيه ذكر قعدوا معهم وحف بعضهم بعضا بأجنحتهم حتى يملؤا ما بينهم وبين السماء الدنيا فإذا تفرقوا عرجوا وصعدوا إلى السماء قال فيسألم الله عز وجل وهو
أعلم بكم من أين جئتم فيقولون جئنا من عند عباد لك في الأرض يسبحونك ويكبرونك ويهللونك ويحمدونك ويسألونك قال وماذا يسألوني قالوا يسألونك جنتك قال وهل رأوا جنتي قالوا لا أي رب قال فكيف لو رأوا جنتي قالوا ويستجيرونك قال ومم يستجيرونني قالوا من نارك يا رب قال وهل رأوا ناري قالوا لا قال فكيف لو لو رأوا ناري قالوا ويستغفرونك قال فيقول قد غفرت لهم فأعطيتهم ما سألوا وأجرتم مما استجاروا قال فيقولون رب فيهم فلان عبد خطاء إنما مر فجلس معرم قال فيقول وله غفرت هم القوم لا يشقى بكم جليسهم

Selain diriwayatkan oleh Muslim, hadis ini juga diriwayatkan oleh Ahmad dan alHakim. Hadis ini berkualitas shahih. Jalur sanad periwayatan hadis ini adalah melalui Muhammad bin Hatim bin Maimun, Bahz, Wahib, Suhail, Abu Suhail, dan Abu Hurairah. Kualitas hadis ini shabih lidzatibi karena sudah ditakhrij oleh imam Muslim dan tecantum dalam kitab shabibnya.

Hadis ini menjelaskan tentang perjalanan para malaikat untuk mencari majlis zikir, apabila mereka mendapatkannya maka mereka itu duduk dalam majlis tersebut hingga akhir acara majlis, lalu mereka kembali lagi ke langit, lalu Allah bertanya kepada mereka dan sebenarnya Dia lebih mengetahui dari merea, dari mana saja kalian? Malaikat menjawab kami baru datang dari hamba-hambaMu membaca tasbih, takbir, tahlil, dan tahmid seraya bermohon kepada Engkau. Allah bertanya: Apa yang mereka minta? Malaikat menjawab mereka memohon surga, dan dijauhkan dari neraka, memohon ampunan dariMu. Lalu Allah berkata: mereka telah diampuni dan telah dikabulkan semua permohonan mereka, kemudian salah satu malaikat menyatakan ada

17 Muslim, op.cit..Cd Maktabah 
seseorang di antara mereka yang kebetulan lewat dan ikut duduk dengan mereka, Allah menjawab: Aku telah mengampuni mereka semua.

Hadis ini menjelaskan tentang keutamaan majlis zikir, bahwa mereka akan mendapat ampunan dari Allah, meraih surga, dan dijauhkan dari neraka.

\section{Hadis Kedua}

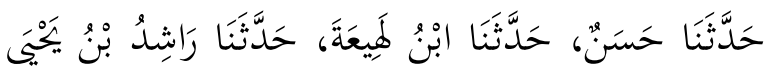

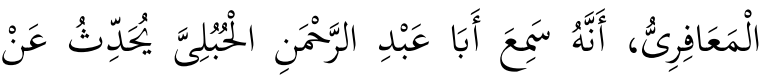

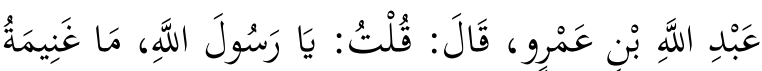

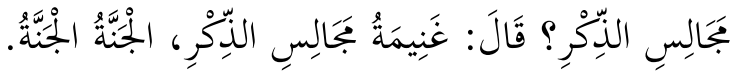

Hadis ini diriwayatkan oleh Ahmad dari Hasan dari Ibnu Lah'ah dari Rasyad bin Yahya al-Ma'afir dari Abu Abdirrahman alHubl dari Abdullah bin Amru. Sanad hadis ini berkualitas dhaif karena ada perawinya yang dinilai dhaif yaitu Ibn Lahi'ah.

Hadis ini menjelaskan tentang ghanimah majalis zikir, kata ghanimah berarti harta rampasan perang. Kalau dikaitkan dengan majalis zikir tidak tepat kalau diartikan harta rampasan perang, namun lebih tepat diartikan dengan pahala atau balasan. Dalam hadis ini Abdullah bin Amru bin Ash bertanya kepada Rasulullah tentang ghanimah majalis zikir, lalu beliau menjawab bahwa ghanimahnya adalah surga.

\section{Memaknai Istilah $A h l a d z-D z i k t$}

Terdapat dua versi hadis yang memakai istilah ini, yaitu:

Hadis Pertama,

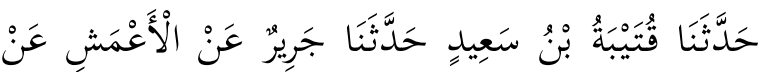

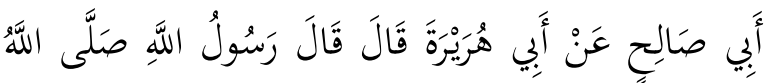

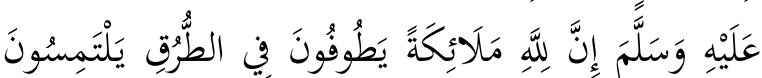

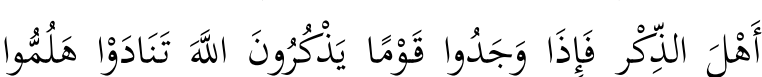

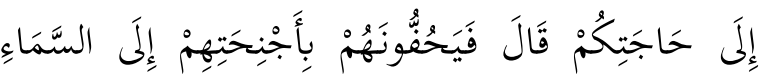

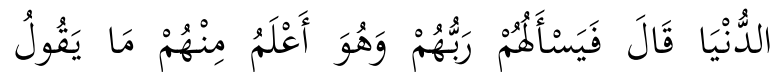

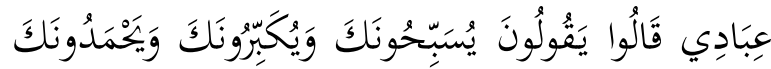

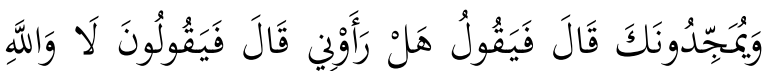

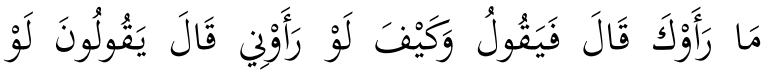

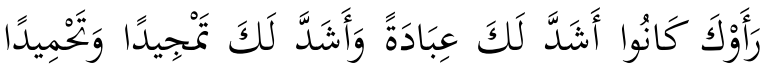

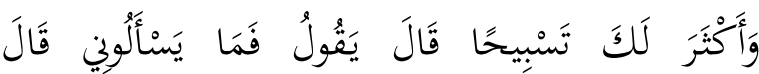

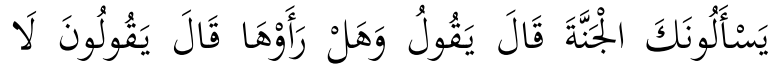

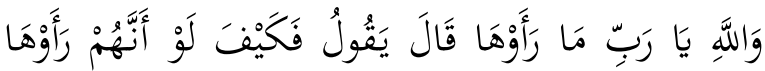

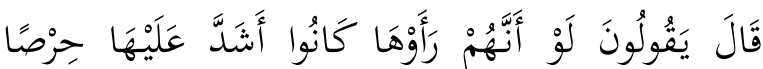

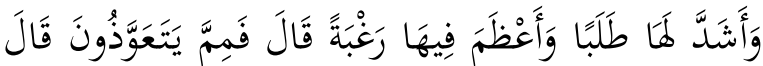

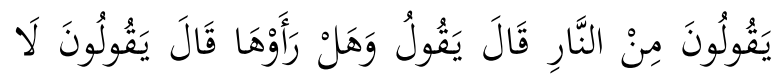

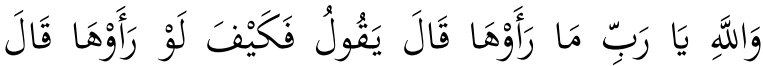

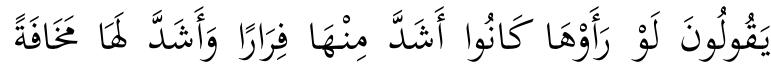

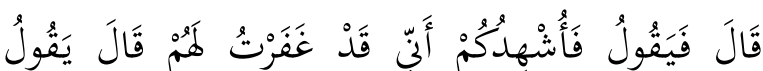

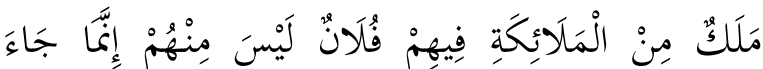

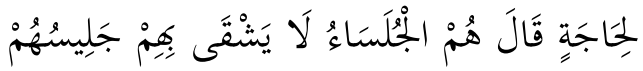

Hadis ini diriwayatkan oleh Bukhari dengan jalur sanad dari Qutaibah bin Sa'id, Jarir, al-A'masy, Abu Shalih dan Abu Hurairah, karena sudah ditakhrij oleh Imam Bukhari, dan hadis ini tercantum dalam kitab shahihnya, maka kualitas hadis ini adalah shabih.

Matan hadis ini sama dengan hadis yang menjelaskan tentang majlis qikir. Adapun perbedaannya hanya pada pemakaian kata abli zikir dan majelis zikir.

\section{Hadis Kedua,}

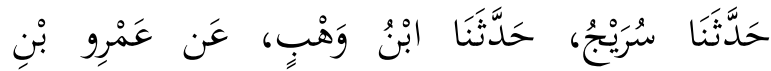

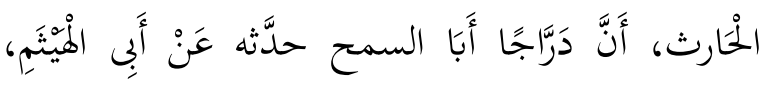




$$
\begin{aligned}
& \text { عَنْ أَبْى سَعِيدٍ، عَنْ رَسُولِ اللَّهِ صلى الله عليه وسلم }
\end{aligned}
$$

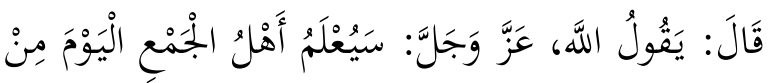

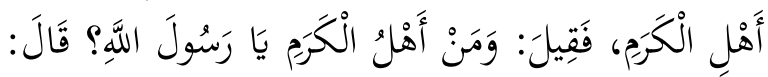

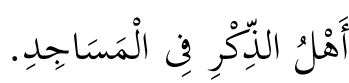

Selain diriwayatkan oleh Abu Ya'la, hadis ini juga diriwayatkan oleh Ahmad, kedua jalur hadis ini bertemu pada Darraj dari Abu al-Haitsam dari Abu Sa'id al-Khudri. Sanad hadis ini berkualitas dha'if, karena ada perawi pada sanad hadis ini yang dinilai dha'if, yaitu Darraj.

Kalau memperhatikan matan hadis ini, dapat terlihat bahwa hadis ini merupakan hadis qudsi, karena dalam matan hadis ada kalamullah yang dilafalkan oleh Nabi, yaitu;

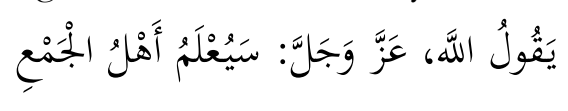

Dalam hadis ini dijelaskan bahwa pada hari kiamat nanti yaitu pada hari dikumpulkannya manusia akan diketahui di antara mereka yang merupakan kelompok orang-orang mulia. Maka sahabat bertanya pada Rasulullah tentang kelompok tersebut, dan Rasulullah menjawab bahwa kelompok itu adalah kelompok ablu zikir yang berzikir di dalam masjid.

\section{Memakai Istilah al-Mufarridin}

Ada dua hadis yang memakai istilah ini yang mengindikasikan adanya zikir berjama'ah, yaitu

Hadis Pertama,

حدثنا أمية بن بسطام العيشي حدثنا يزيد يعني بن زريع حدثنا روح بن القاسم عن العلاء عن أبيه عن أبي هريرة قال **كان رسول الله صلى الله عليه وسلم يسير في طريق مكة فمر على جبل يقال له جمدان فقال

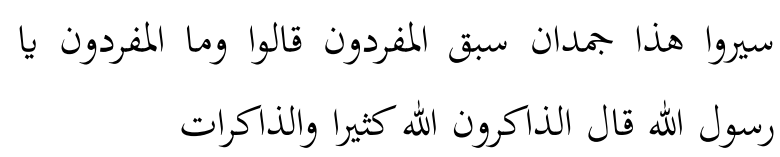

Hadis ini diriwayatkan oleh Muslim, dan berkualitas shabih. Karena hadis yang diriwayatkan Muslim termasuk hadis yang sudah diakui keshahihannya.

Hadis ini menjelaskan tentang almufarridun, menurut Ibn Qutaibah almufarridun adalah orang-orang yang menjauh dari sanak keluarganya dan menuju suatu tempat yang sunyi untuk dapat selalu melakukan qikrullah. Dalam hadis ini almufarridun diartikan dnegan kelompok orang baik laki-laki maupun perempuan yang banyak melakukan qikrullah

Hadis dari Abu Hurairah ini menceritakan di saat Rasulullah dan beberapa sahabat berjalan menuju Mekkah, mereka melewati gunung yang disebut dengan Jumdan, maka Rasulullah bersabda lewatilah jumdan ini niscaya akan bertemu dengan mufarridun yaitu orang-orang yang banyak berzikir baik laki-laki maupun perempuan.

Hadis Kedua,

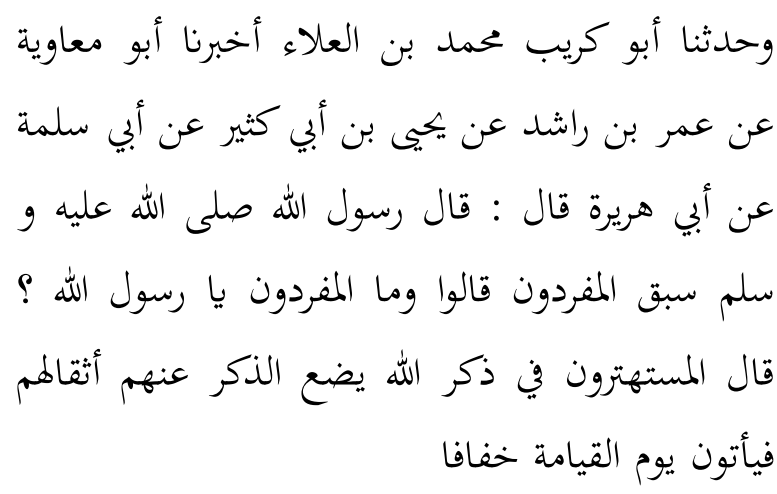

Selain diriwayatkan oleh at-Tirmidzi, hadis ini juga diriwayatkan oleh Ahmad dan alHakim. Jalur sanad Ahmad dan Hakim bertemu pada Ali bin al-Mubarak dan kedua jalur ini bertemu dengan jalur at-tirmizi pada Yahya bin Katsir dari Abu Salamah dari Abu Hurairah. 
Abu Salamah meriwayatkan hadis ini dari Abu Hurairah dari Rasulullah. Sanad hadis ini berkualitas dha'if, karena ada perawinya yang dha'if, yaitu Umar bin Rasyid

Hadis ini mengartikan kata almufarridun dengan orang-orang yang membiasakan dirinya berzikir dan menjadikan zikir sebagai kewajiban yang harus dipikul di pundaknya, dan ganjarannya nanti mereka akan berjalan di hari kiamat dengan pundak yang ringan dan terbebas dari segala beban.

\section{PEMAHAMAN TERHADAP HADIS- HADIS TENTANG ZIKIR JAMA'I}

Indikasi hadis yang menunjukkan praktek zikir bersama adalah dari istilah yang mengisyaratkan adanya suatu kumpulan orang, seperti istilah kaum, mala', majelis zikir, almufarridun, abl zikir, dan sebagainya..

Pelaksanaan zikir berjama'ah atau zikir bersama secara langsung tidak dipraktekkan oleh Nabi Saw, namun di antara sahabat ada yang melakukan hal tersebut, sedangkan Nabi tidak melarang mereka. Bahkan di dalam hadisnya, Nabi banyak menyebutkan keutamaan-keutamaan bagi kelompokkelompok yang berzikir kepada Allah.

Adapun mengenai praktek zikir berjama'ah apakah dibaca dengan suara jahr ataukah sir, hal ini juga menjadi perdebatan di kalangan ulama. Menurut penulis, ada indikasi kebolehan untuk berzikir dengan suara yang jahr, sebagaimana yang tercantum dalam hadis shahih yang menggunakan kata malain.. Ibn hajar memahami dzakara fi malain dengan makna dzakarani jahran. Artinya adalah mengeraskan suara di saat ada banyak orang yang akan mendengarnya.

Namun tidak dapat dipungkiri bahwa ada juga hadis yang mengatakan bahwa ketika berzikir tidak perlu keras karena Allah tidak tuli. Pembahasan khusus mengenai berzikir secara sirr ataukah jahr tidak penulis lakukan secara mendalam, mengingat yang menjadi fokus utama kajian ini adalah zikir berjama'ah.

Untuk itu penulis setuju dengan pendapat ulama yang mengatakan kebolehan zikir berjama'ah, karena hadis-hadis yang mengindikasikan kebolehan tersebut jumlahnya banyak dan kualitasnya hadisnya kuat dan saling mendukung(tidak ada pertentangan).

Pendapat Ulama Tentang Status Zikir

Berjamaah

Zikir berjamaah telah menimbulkan kontroversi antara ulama. Sebagian menyebutnya sebgai bid'ah namun sebagian lain menyebutnya sebagai sunnah. Alasan dikatakan sebagai bid'ah karena ketiadaan dalil asal dari amal ini. Amal ini tidak tsubut dari Nabi.

Ibn Utsaimin ketika ditanya perihal zikir berjamaah berpendapat bahwa itu adalah bid'ah. Ia menolak zikir berjamaah, namun menerima zikir jahran sebagaimana kutipan di bawah ini.

Zikir berjama'ah adalah bid'ah tidak ada dari Nabi, yang ada banyalah semua orang beristigfar dan berrikir sendiri. Namun juga sunnah menjaharkan qikir setelah shalat, karena telab tsubut dari Ibn Abbas. Berzikir dengan mengeraskan suara ada ketika selesai shalat. Ini dalil terbadap sunnabnya menjaharkan zikir. Berbeda dengan yang banyak dilakukan oleb banyak orang hari ini yang mensirkannya. Sebahagian menjaharkan tablil. Sedangkan tasbih, tahmid dan takbir tidak. Aku tidak tahu asal muasal sunnabnya yang membedakan ini dan ini. Cuma yang sunnah adalab jabr.

Sebagian ulama berpendapat bahwa berzikir berjamaah adalah sunnah. Bahkan alSya'rani menyatakan bahwa zikir jamaah itu telah disepakati sunnahnya oleh para ulama, baik salaf maupun khalaf. Hukumnya mustabab. Pendapat lainnya dikemukakan oleh Sayyid Sabiq di dalam Figh Al-Sunnab. Ia membahas persoalan zikir berjamaah ini dalam sub bab 
istishab majalis al-dqikeri. Ia juga menggunakan ungkapan halaqah zikir. Hal yang menarik adalah ia menjatuhkan hukum mustahab untuk majelis zikir tersebut. Namun ia tidak menyebutkan kata berjamaah.

Begitupun al-Nawawi menilainya mustahab. Ia mengkhususkan pembahasan zikir dalam satu kitab yang diberi nama al-adzkar alnawawiya. Yang menarik adalah ia mengakui kesunnahan zikir begitupun berkumpul untuk berzikir.

Berdasarkan interpretasi kedua pemahaman ulama dan perbedaan mereka dalam menginterpretasikannya memungkinkan kedua bentuk pelaksanaan zikir tersebut dapat diamalkan.

\section{KESIMPULAN}

Hadis yang menunjukkan praktek Nabi secara langsung melaksanakan zikir berjam'ah memang tidak ditemukan, namun hadis- hadis qauli Nabi banyak mengemukakan keutamaankeutamaan bagi kaum yang melaksanakan zikir berjama'ah.

Hal ini menunjukkan bahwa pelaksanaan zikir berjamaah dalam perspektif hadis adalah suatu hal yang dibolehkan, bahkan ada ulama yang menilainya sebagai hal yang sunnah. 


\section{DAFTAR KEPUSTAKAAN}

Al Khomis, Muhammad bin Abdurrahman, Zikir Jama'I bainal ittiba wa ibtida', Al Manshurah, Dar Al Huda An Nabawi, 2004

Al-Naisaburi, Abu al-Husain Muslim bin al-Hajjaj Shabih Muslim, dalam Maktabah Syamilah

Al-Qazwini, 'Abdillah Ibn Majah, Sunan Ibn Majah, Beirut: Dar al-Fikr, tth

Al-Tirmidzi, Abu 'Isa, Sunan al-Tirmidæri, Beirut: Dar al-Fikr, 1403 H/1983 M

Bukhari, Muhammad bin Ismail bin Ibrahim al-mughirah bin bardazbab, Shahih Bukhari, dalam Maktabah Syamilah

Hakim, Lukmanul, Tuntunan Hadis Tentang Zikir, Padang: Hayfa Press, 2013

Masyharuddin, Pemberontakan Tasawnf, Surabaya :Stain Press Kudus, 2007

Masyhudi, In'ammuzahiddin, Nurul Wahyu A, Berzikir dan Sehat ala Ustad Haryono, Semarang: Syifa Press, 2006

Moleong, Lexy J, Metodologi Penelitian Kualitatif, (Bandung: Remaja Rosdakarya, 2008

Sabiq, Sayid, Fiqh al-Sunnah, Beirut: Dar al-Fikr, 1400 H/980 M

Ash-Shiddieqy, T.M. Hasbi, Pedoman Zikir dan Doa. Jakarta: Bulan Bintang, 1982 
Halaman ini tidak disengaja kosong 